IRA-International Journal of Applied Sciences ISSN 2455-4499; Vol.05, Issue 02 (2016)

Institute of Research Advances

Pg. no. 74-84

http://research-advances.org/index.php/IRAJAS

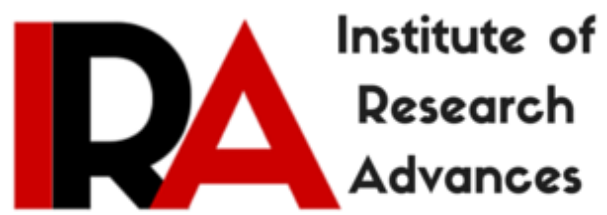

\title{
Assessment of Groundwater Quality, with special reference to Fluoride Contamination in Bhopalpatnam Block, District Bijapur, Chhattisgarh, India
}

\author{
Korsa Munna ${ }^{1}$, Rajeeva Guhey ${ }^{2}$ and D.C. Jhariya ${ }^{3}$ \\ 1,2 Department of Geology, \\ Government N.P.G. College of Science Raipur,(C.G.), India. \\ ${ }^{3}$ Department of Applied Geology, \\ National Institute of Technology, (NIT) Raipur, 492010(C.G.), India.
}

Type of Review: Peer Reviewed.

DOI: http://dx.doi.org/10.21013/jas.v5.n2.p3

\section{How to cite this paper:}

Munna, K., Guhey, R., \& Jhariya, D. (2016). Assessment of Groundwater Quality, with special reference to Fluoride Contamination in Bhopalpatnam Block, District Bijapur,Chhattisgarh, India. IRA-International Journal of Applied Sciences (ISSN 24554499), 5(2), 74-84. doi:http://dx.doi.org/10.21013/jas.v5.n2.p3

(C) Institute of Research Advances

\section{(cc) EY-NC}

This work is licensed under a Creative Commons Attribution-Non Commercial 4.0 International License subject to proper citation to the publication source of the work.

Disclaimer: The scholarly papers as reviewed and published by the Institute of Research Advances (IRA) are the views and opinions of their respective authors and are not the views or opinions of the IRA. The IRA disclaims of any harm or loss caused due to the published content to any party. 


\section{ABSTRACT}

Groundwater samples were collected for physico-chemical analysis during pre-monsoon period (May, 2015) from fluoride affected Bhopalpatnam block, District-Bijapur. The major objective of this study was to locate the vulnerable areas of fluoride contamination. The results reveal that the fluoride concentration in the existing groundwater in Bijapur-District is ranging from 0.1 to $3.58 \mathrm{mg} / \mathrm{l}$. It is found that the study area is affected mostly by high Fluoride concentration and is evident from the 59\% of total samples collected showing >1.5 mg/l of Fluoride concentration, which is a maximum permissible limit suggested by Bureau of Indian Standard [9].The evaluation of physico-chemical parameters reflects that weathering of granitic rocks are responsible for major ion chemistry of groundwater in Bhopalpatnam area. This study will be helpful in solving problem related to drinking water in the study area.

Keywords: Fluoride contamination, Groundwater quality, Granitic rocks, Bhopalpatnam area, Bajapur.

\section{INTRODUCTION}

Fluoride $\left(\mathrm{F}^{-}\right)$is essential in small quantity for prevention of dental caries, however, its higher content $(>1.5$ $\mathrm{mg} / \mathrm{l})$ in drinking water causes fluorosis [9].High $\left(\mathrm{F}^{-}\right)$contamination in groundwater has been reported in different parts of the world, especially in arid and semi-arid climatic regions [6]. Fluorosis is the most prevailing groundwater-related disease in India, 20 out of 29 states have some extent of groundwater fluoride contamination, impacting 85-97\% of districts in some states. This problem is noticed in almost all the states such as Andhra Pradesh, Bihar, Chhattisgarh, Gujarat, Madhya Pradesh, Punjab, Rajasthan, Tamil Nadu and Uttar Pradesh. About 62 million people of India presently are at risk of fluorosis from the consumption of high fluoride through the groundwater [1].The amount of $\left(\mathrm{F}^{-}\right)$occurringnaturally in groundwater is governed principally byclimate, composition of the host rocks and hydrogeology[6].Granite rocks contain a relative abundance of ( $\left.\mathrm{F}^{-}\right)$bearing minerals (apatite, fluorite, biotitic and hornblende). They are the main source of $\mathrm{F}^{-}$in groundwater [21-20-2-14-26-6-22-10].Fluoride leaches out and contaminates the adjacent water and soil resources. Fluorine commonly occurs as a negatively charged ion inwater, either in trace amounts or as a major ion with high concentrations [12-2-11].Though both hard rock and sedimentary formations are existing, hard-rock formation constitutes $90 \%$ of total geographical area. Most commonhard-rock formations are gneisses and charnockite of Achaean age.The granitic terrain of Archaean age found in most partof the central southern India is one such area with arid climateand irrigation activity. The study focuses on physico-chemical parameters of the groundwater with special emphasis on fluoride contamination and their possible sources from Bhopalpatnam granulite belt, (Bastar Craton), around Bhopalpatnam area.

\section{STUDY AREA}

The study area is situated about $54 \mathrm{~km}$ west from BijapurDistrict andtotal 23 villages included in the survey.During field survey, we observed that, many children and adults have been affected by dental fluorosis. The study area consists of six watershed of Chintavagu, two watershed of Jalavagu and one watershed of Indravati river (Fig.1).The total area is $165.71 \mathrm{~km}^{2}$ comprising 9 mini watersheds namely Goralavagu watershed $\left(31.93 \mathrm{~km}^{2}\right)$, Burguvagu watershed $\left(13.35 \mathrm{~km}^{2}\right)$, Tigalvagu watershed $\left(47.06 \mathrm{~km}^{2}\right)$, Rudraramvagu watershed $\left(3.93 \mathrm{~km}^{2}\right)$, Bandalvagu watershed $\left(32.23 \mathrm{~km}^{2}\right)$, Rampuramvagu watershed $(6.96$ $\left.\mathrm{km}^{2}\right)$, Nerlavagu watershed $\left(13.58 \mathrm{~km}^{2}\right)$, Chillamarkavagu watershed $\left(7.60 \mathrm{~km}^{2}\right)$ and Timed vagu watershed $\left(9.07 \mathrm{~km}^{2}\right)$, falls within longitudes $80^{0} 20^{\prime} 00^{\prime \prime}$ to $80^{0} 31^{\prime} 43^{\prime}$ "and latitudes $18^{0} 47^{\prime} 30^{\prime \prime}$ to $18^{0} 55^{\prime} 28^{\prime \prime}$ (Fig. 1).The peopleof the study area are economically backward main occupation of villagers is agriculture. 

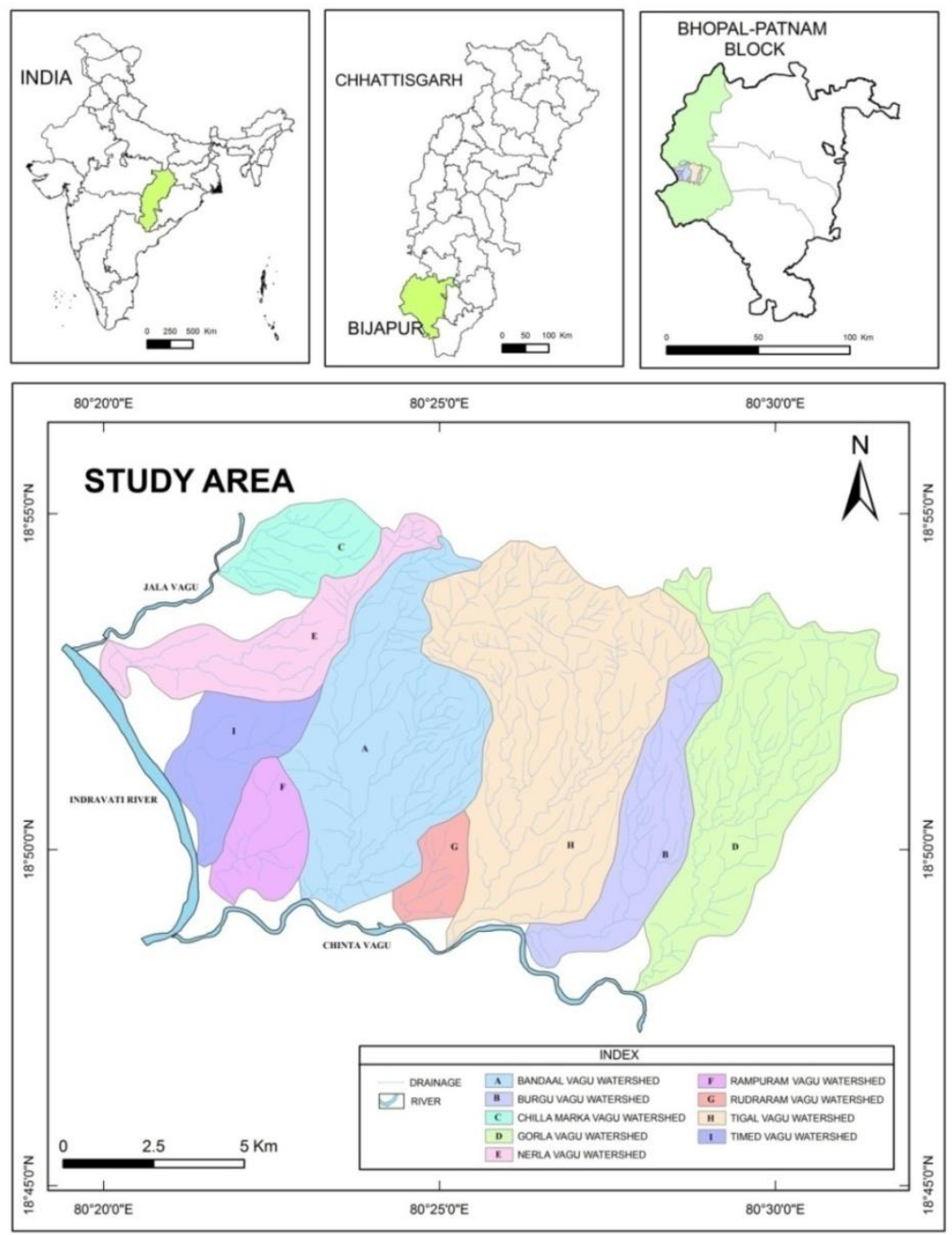

Figure.1 Location map of the study area.

\section{GEOLOGY AND HYDROGEOLOGY}

The regionally study area is a part of Peninsular Shield which is divisible into two distinct crustal provinces; namely the Southern Crustal Province and the Northern Crustal Province, both are separated by the Central Indian Tectonic Zone [19-28-24-27]. The southern Crustal Province consists of important ArchaeanCratonic nuclei (>3.0Ga) such as Dharwar,Bastar and Singhbhum, whereas, the Northern Crustal Province consists of BundelkhandCraton. Dharwar,Bastar and Singhbhumcratons are exposed across the NW-SE trending Pranhita-Godavari and Mahanadi basins.The Bastarcraton is flanked by the Chhattisgarh basin in the NortheasternGhatskhondalite-charnockite suite in the east gneissic complex in the south and Pranhita-Godavari basin in the southwest [16]. As far as the granulite belts are concerned, the BastarCraton consists of three important granulite belts namely the Kondagaon Granulite Belt, the Bhopalpatnam Granulite Belt and the Konta Granulite Belt [16-].The NNW-SSE trending ca.20-40 kms wide and $300 \mathrm{kms}$ long Bhopalpatnam Granulite Belt is located at the south-western edge of the BastarCraton [24-27].

The study area is underlain by basement crystalline granite,gneisses, charnockitesbelonging to the Bengpal group and at placesintruded by dykes and pegmatite veins. These rocks are weathered and fractures at 
bottom, are considered good aquifer for accumulation ground water. In general, the shallow fractured zone lies approximately 70-80 m. depth and the yield groundwater 3 to 5 lps. Approx. The Bengpal Group are overlain by the rocks of Pakhal Group in the N W of the study area, which exhibits arenite, argillites and carbonate rock sequence respectively. Recent alluvium, and pliestocene laterite, clay, arenite, argillite and sand cover 10 to 30 m.thick present at the top.

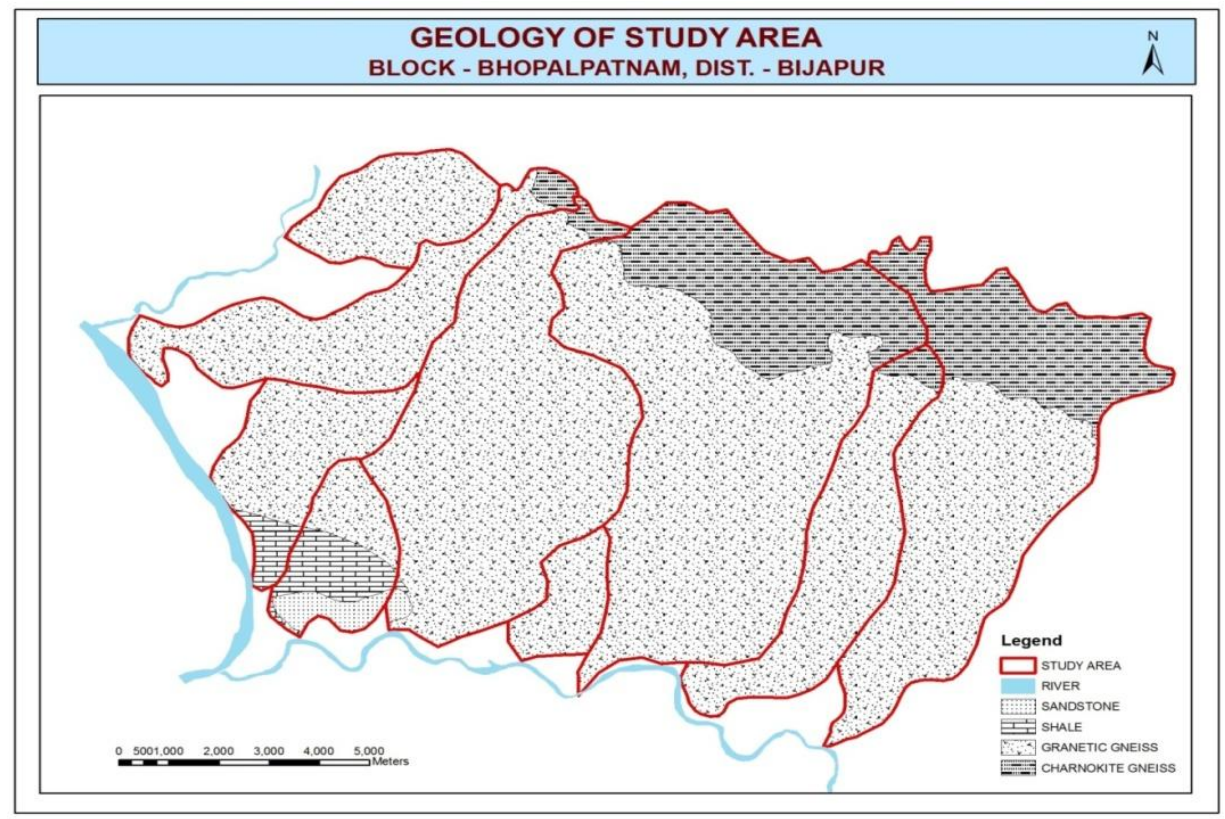

Figure.2 Geological map of the study area.

\section{MATERIALS AND METHODS Sampling and analysis}

A systematic sampling was carried out in the pre-monsoon period during May, 2015. Total 57 nos. groundwater samples were collected in pre-washed polythene, narrow mouth, bottles from deep aquifers and the bottles were rinsed twice before sampling. A special care has been given to those areas where the fluoride contamination was expected. Based on this study, representative wells were selected. The location of these samples is shown in (Fig.3). The water samples from the bore wells were collected after pumping out water for about 10 minutes remove stagnant water from the well. Samples are immediately transferred to pre-cleaned polythene bottles with $500 \mathrm{ml}$. capacity. Collected samples were preserved at $4^{\circ} \mathrm{C}$ and taken to the laboratory for analysis. Analysis of groundwater samples for evaluation of chemical parameters were done as per Standard Methods [3] procedure, from CGCOST central laboratory Raipur (C.G.).

The Chemical parameters considered were $\mathrm{pH}$ (hydrogen ion concentration), EC (electrical conductivity), TDS (total dissolved solid), TH (total hardness) and concentrations of all major cations like Ca (calcium), $\mathrm{Mg}$ (magnesium), $\mathrm{Na}$ (sodium) and $\mathrm{K}$ (potassium) and anions like $\mathrm{Cl}$, (chloride), $\mathrm{HCO}_{3}$ (bicarbonate), $\mathrm{F}$ (fluoride), $\mathrm{SO}_{4}$ (sulfate) and $\mathrm{NO}_{3}$ (nitrate $\mathrm{N}$ ). The $\mathrm{pH}$ and electrical conductivity respectively were measured by using $\mathrm{pH}$ meter and conductivity meter. $\mathrm{CO}_{3}$ and $\mathrm{HCO}_{3}$ concertation were determined using acid titration method, Alkalinity and Phosphate were determined by titration method, $\mathrm{Cl}$ concentration by the $\mathrm{AgNO}_{3}$ titration method, $\mathrm{SO}_{4}$ concentration by the $\mathrm{BaCl}_{3}$ method using spectrophotometer and $\mathrm{NO}_{3}$ concentration by the titration method. $\mathrm{Na}$ and $\mathrm{K}$ were analyzed using Micro Processor Flame Photometer, 
$\mathrm{Ca}$ and $\mathrm{F}$ were analyzed by Cary,100 Bio, UV-visible spectrophotometer, $\mathrm{Mg}$ and $\mathrm{Fe}$ were analyzed by using Atomic AbsorptionSpectrometer (AAS) and TDS of the groundwater was determined by the following equation: TDS in $\mathrm{mg} / \mathrm{l}=\mathrm{EC} * 0.67$. Aquachem software, Microsoft Excel and ArcGIS 9.2 software were used in the data analysis and interpretation. Statistical parameters of analyzed groundwater sample during Pre-monsoon is given in Table 1.

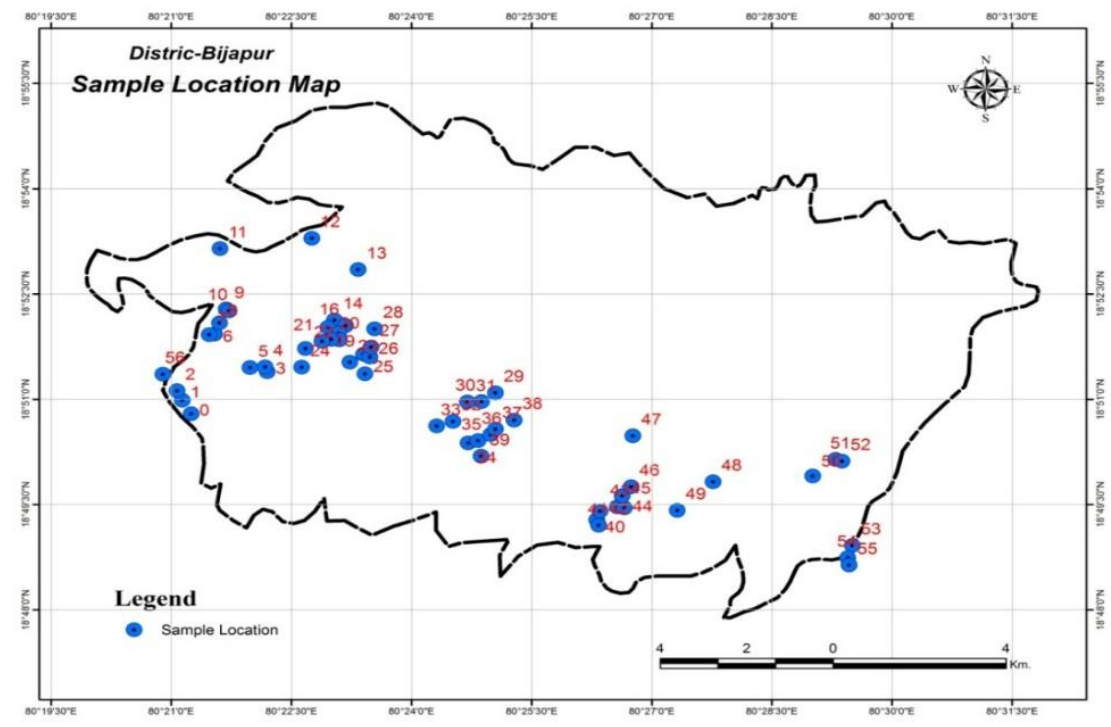

Figure.3 Sample location map of the study area.

Table 1: Statistical parameters of groundwater Sample during Pre-Monsoon.

\begin{tabular}{|c|c|c|c|c|}
\hline Parameters & Minimum & Maximum & Average & Standard Deviation \\
\hline pH & 6.14 & 8.72 & 7.34 & 0.33 \\
\hline EC & $2.08 \mu \mathrm{mohs} / \mathrm{cm}$ & $1799 \mu \mathrm{mohs} / \mathrm{cm}$ & $995.74 \mu \mathrm{mohs} / \mathrm{cm}$ & $382.24 \mu \mathrm{mohs} / \mathrm{cm}$ \\
\hline TDS & $1.39 \mathrm{mg} / \mathrm{l}$ & $1205.33 \mathrm{mg} / 1$ & $667.1 \mathrm{mg} / 1$ & 256.10 \\
\hline Alkalinity & $190 \mathrm{mg} / \mathrm{l}$ & $580 \mathrm{mg} / 1$ & $399.3 \mathrm{mg} / \mathrm{l}$ & $82.63 \mathrm{mg} / \mathrm{l}$ \\
\hline Hardness & $190 \mathrm{mg} / \mathrm{l}$ & $1740 \mathrm{mg} / \mathrm{l}$ & $415.09 \mathrm{mg} / \mathrm{l}$ & $218.35 \mathrm{mg} / \mathrm{l}$ \\
\hline $\mathbf{C a}$ & $34.58 \mathrm{mg} / \mathrm{l}$ & $333.78 \mathrm{mg} / \mathrm{l}$ & $80.36 \mathrm{mg} / \mathrm{l}$ & $42.62 \mathrm{mg} / 1$ \\
\hline Mg & $0 \mathrm{mg} / \mathrm{l}$ & $245.9 \mathrm{mg} / \mathrm{l}$ & $51.19 \mathrm{mg} / \mathrm{l}$ & $44.99 \mathrm{mg} / \mathrm{l}$ \\
\hline $\mathbf{N a}$ & $0 \mathrm{mg} / \mathrm{l}$ & $210 \mathrm{mg} / 1$ & $69.24 \mathrm{mg} / \mathrm{l}$ & $42.79 \mathrm{mg} / \mathrm{l}$ \\
\hline $\mathbf{K}$ & $0.34 \mathrm{mg} / 1$ & $48.8 \mathrm{mg} / \mathrm{l}$ & $3.37 \mathrm{mg} / 1$ & $8.66 \mathrm{mg} / \mathrm{l}$ \\
\hline $\mathrm{CO}_{3}$ & $13.2 \mathrm{mg} / \mathrm{l}$ & $58.8 \mathrm{mg} / \mathrm{l}$ & $33.56 \mathrm{mg} / \mathrm{l}$ & $10.46 \mathrm{mg} / \mathrm{l}$ \\
\hline $\mathrm{HCO3}$ & $64.05 \mathrm{mg} / \mathrm{l}$ & $405.65 \mathrm{mg} / \mathrm{l}$ & $239.53 \mathrm{mg} / \mathrm{l}$ & $72.88 \mathrm{mg} / \mathrm{l}$ \\
\hline $\mathrm{Cl}$ & $30 \mathrm{mg} / 1$ & $360 \mathrm{mg} / \mathrm{l}$ & $90.7 \mathrm{mg} / \mathrm{l}$ & $61.44 \mathrm{mg} / \mathrm{l}$ \\
\hline $\mathrm{SO}_{4}$ & $0 \mathrm{mg} / \mathrm{l}$ & $834.4 \mathrm{mg} / \mathrm{l}$ & $47.51 \mathrm{mg} / 1$ & $117.31 \mathrm{mg} / 1$ \\
\hline PO4 & $0 \mathrm{mg} / \mathrm{l}$ & $1 \mathrm{mg} / 1$ & $0.06 \mathrm{mg} / \mathrm{l}$ & $0.17 \mathrm{mg} / \mathrm{l}$ \\
\hline $\mathrm{NO}_{3}$ & $25 \mathrm{mg} / 1$ & $65 \mathrm{mg} / 1$ & $38.77 \mathrm{mg} / \mathrm{l}$ & $8.03 \mathrm{mg} / \mathrm{l}$ \\
\hline $\mathbf{F}$ & $0.1 \mathrm{mg} / 1$ & $3.58 \mathrm{mg} / 1$ & $1.71 \mathrm{mg} / \mathrm{l}$ & $0.88 \mathrm{mg} / \mathrm{l}$ \\
\hline $\mathbf{F e}$ & $0 \mathrm{mg} / \mathrm{l}$ & $4.65 \mathrm{mg} / 1$ & $0.73 \mathrm{mg} / \mathrm{l}$ & $0.84 \mathrm{mg} / \mathrm{l}$ \\
\hline
\end{tabular}




\section{Spatial distribution}

The major chemical parameters in the groundwater is spatially in (Fig.4) prepared using the ArcGIS 9.2 software.The spatial diagrams show the variation of the different chemical parameters spatially over the study area.Spatial distribution of $\mathrm{F}^{-}$is illustrated in (Fig.4) progressive increase in $\mathrm{F}^{-}$concentration is observed from South-east to North-west with isolated patches of low and high ranges of $\left(\mathrm{F}^{-}\right)$. It suggests that the $\left(\mathrm{F}^{-}\right)$content is not uniformly distributed. The influence of geogenic sources (soil and rock forming minerals) to control the elevated $\left(\mathrm{F}^{-}\right)$content in the groundwater.From the spatial analysis, the regions around Bhopalpatnam area were seemed to be highly $\left(\mathrm{F}^{-}\right)$contaminated in the groundwater.

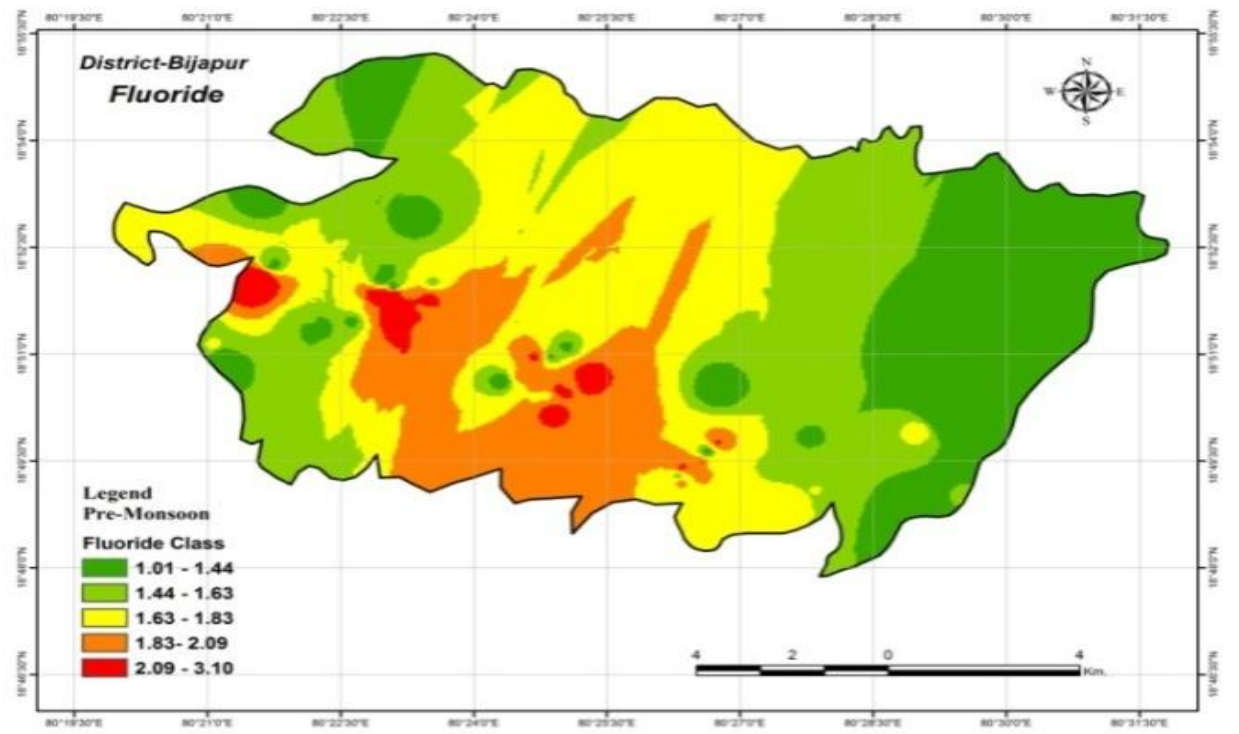

Figure.4. Spatial distribution map of $\mathrm{F}^{-}$ion concentration in the groundwater.

\section{Geochemical Relationship and Water Type.}

The geochemical evolution of groundwater and the relationship between different dissolved ions can be understood by plotting the geochemical data on Piper trilinear diagram [17] (Fig.5).The data plot on the trilinear diagram shows that majority of groundwater samples fall in no dominant zone in the cation facies and $\mathrm{HCO}_{3}^{-}$and $\mathrm{SO}_{4}^{-}$zone in the anion facies. The plot of geochemical data on diamond-shaped field reveals that the plotted points fall in 1, 3,4 and 5fields (fig.5). 


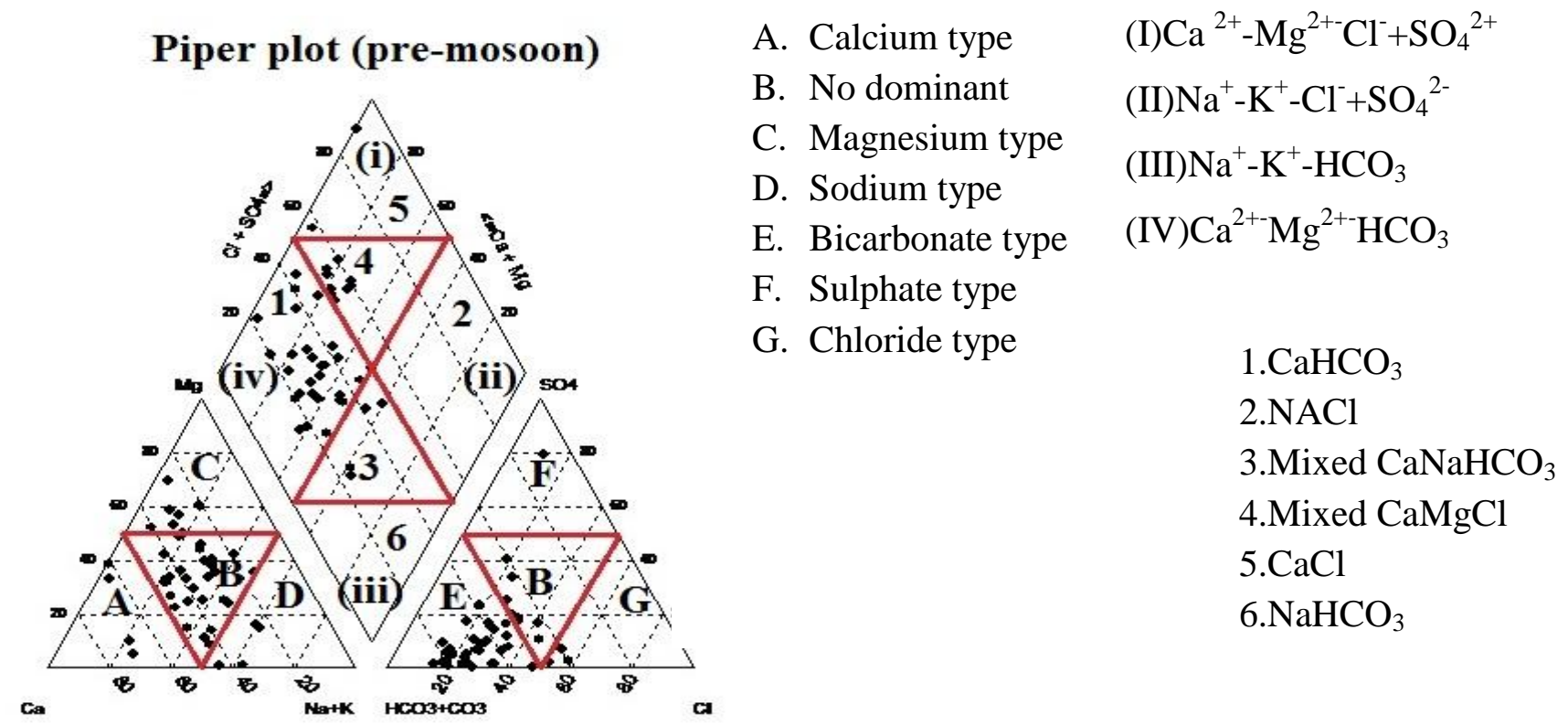

Figure 5.Piper's trilinear diagram showing the relationship between dissolved ions and water type.

The plotted points of all the groundwater samples fall in the region 1, which suggest the dominance of alkaline earths metals $\left(\mathrm{Ca}^{2+}+\mathrm{Mg}^{2+}\right)$ exceeding alkali metal cations $\left(\mathrm{Na}^{+}+\mathrm{K}^{+}\right)$. About $64 \%$ groundwater samples exhibit dominance of $\mathrm{HCO}_{3}{ }^{-}$over $\mathrm{SO}_{4}{ }^{2-+} \mathrm{Cl}^{-}$and plotted points fall in the field 3, while $36 \%$ groundwater samples the total concentrations of $\mathrm{SO}_{4}{ }^{2-}+\mathrm{Cl}^{-}$exceed $\mathrm{HCO}_{3}{ }^{-}$and plotted points fall in the field 4. About $36 \%$ groundwater samples fall in the field 4, indicating a mixed chemical character of groundwater having none of the cation-anion pairs dominates the chemical composition. The facies mapping approach applied to the present study shows that $\mathrm{Ca}^{2+}-\mathrm{Mg}^{2+}-\mathrm{HCO}_{3}^{-}$is the dominant hydrogeochemical facies in $64 \%$, of the groundwater samples while $36 \%$ groundwater samples are mixed chemical character of $\mathrm{Ca}^{2+}-\mathrm{Mg}^{2+}-\mathrm{Cl}^{-}$hydrochemical facies [7].

\section{Gibbs plots.}

Gibbs plots are indicated by the variation diagrams of TDS against the ratios $\left(\mathrm{Na}^{+}+\mathrm{K}^{+}\right) /\left(\mathrm{Na}^{+}+\mathrm{K}^{+}+\mathrm{Ca}^{2+}\right)$ and TDS against $\left(\mathrm{Cl}^{-}+\mathrm{NO}_{3}\right) /\left(\mathrm{Cl}^{-}+\mathrm{NO}_{3}+\mathrm{HCO}_{3}\right)$ for both cations and anions groups. These plots provide very good genetic information about the composition, origin and distribution of the dissolved constituents of groundwater.The major natural mechanisms controlling groundwater chemistry are (i) atmospheric precipitation, (ii) rock weathering, (iii) evaporation and fractional crystallization [13].The groundwater samples of the area are plotted on Gibbs diagrams (Fig.6 a, b).For better knowing controlling mechanisms, according to Gibbs classification the majority of groundwater samples are controlled by rock dominance and a few by precipitation dominance of major cations and anions. 
(a)

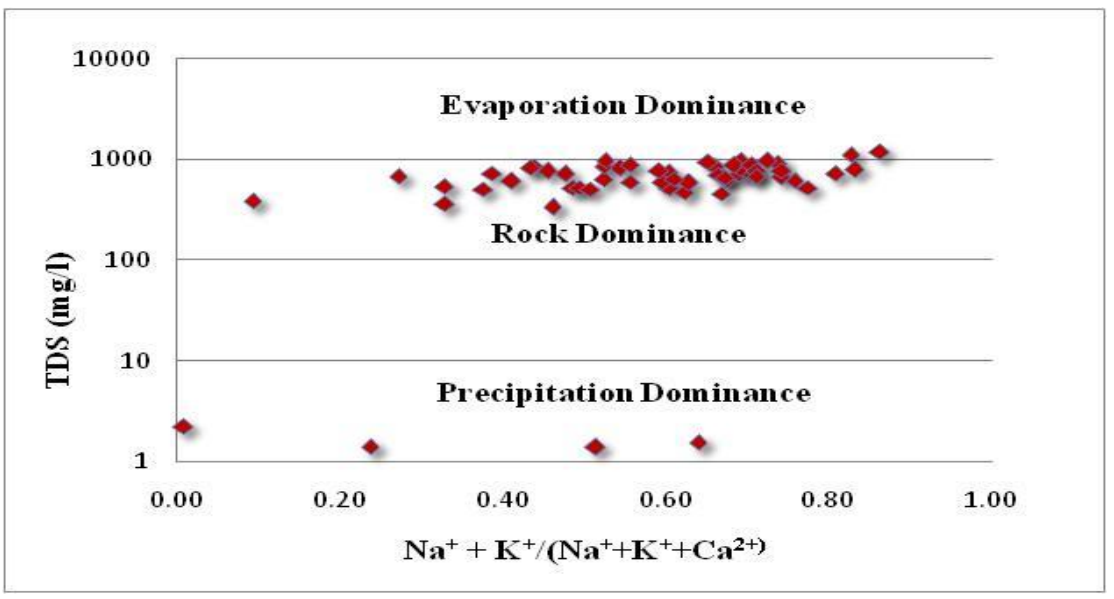

(b)

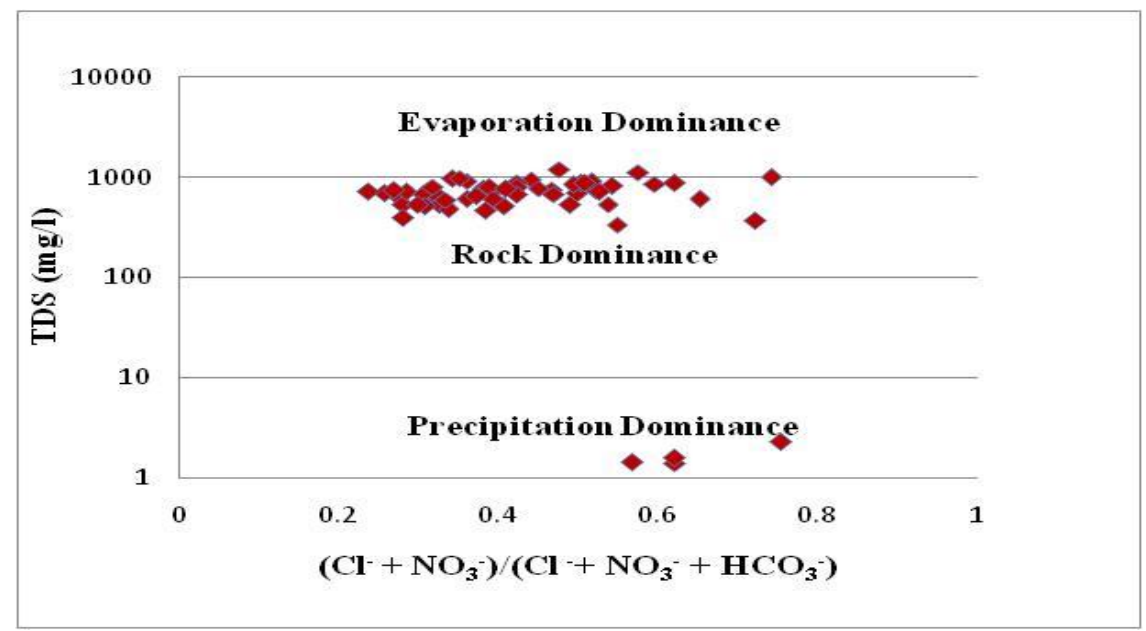

Figure.6 Gibbs diagram representing the ratio of $(\mathbf{a})(\mathrm{Na}+\mathrm{K}) /(\mathrm{Na}+\mathrm{K}+\mathrm{Ca})$ and $(\mathbf{b})\left(\mathrm{Cl}+\mathrm{NO}_{3}\right)$ $/\left(\mathrm{Cl}+\mathrm{NO}_{3}+\mathrm{HCO}_{3}\right)$ as a function of TD

The groundwater samples of the area on the plot TDS versus $\left\{\left(\mathrm{Cl}^{-}+\mathrm{NO} 3\right) /\left(\mathrm{Cl}^{-}+\mathrm{NO}_{3}+\mathrm{HCO}_{3}^{-}\right)\right\}$show similar variation with that of earlier cation diagram (Fig. 6a).However, the samples are shifted from right to left fields due to less $\mathrm{Cl}^{-}$content and high concentration of $\mathrm{HCO}_{3}$. The rock-water interaction may play a major role in the groundwater chemistry of the area [22].Groundwater water has been controlled by more of rock-water interaction and the majority of groundwater samples fall in the fields of rock dominance. A few groundwater samples the pre-monsoon periods show slight increase of precipitation influence (Fig. 6 a \& b).Like groundwater samples have more alkalies, more bicarbonates and less chlorides in their chemistry. In the study area, the major source of $\mathrm{F}^{-}$are gneissic, granites, quartzites and silicate rocks which have high concentration of $\mathrm{F}^{-}(0.1$ to $3.58 \mathrm{mg} / \mathrm{l})$. Important factors that determine concentration of fluoride in groundwater availability and solubility of minerals, $\mathrm{pH}$,Temperature, anion exchange capacity of aquifer materials, type of geological materials and residence time, porosity, structures, depth, groundwater age, concentration of carbonates and bicarbonates in water [2]. 


\section{RESULTS AND DISCUSSION}

The statistical parameters of the analyzed groundwater quality of the Bhopalpatnam block are given in Table 1.The value of $\mathrm{pH}$ varies from 6.14 to 8.72, with an average of 7.34, indicating an alkaline nature of groundwater. The EC ranges from 2.08 to $1799 \mu \mathrm{mohs} / \mathrm{cm}$, with an average of $995.74 \mu \mathrm{mohs} / \mathrm{cm}$, indicating a wide range of variation in the groundwater quality.The concentration of alkalinity is in between 190 and $580 \mathrm{mg} / \mathrm{l}$, and average is $399.3 \mathrm{mg} / \mathrm{l}$, indicating an alkaline nature of groundwater. The concentration of hardness is in between 190 to $1740 \mathrm{mg} / \mathrm{l}$, and average is $415.09 \mathrm{mg} / \mathrm{l}$. the groundwater comes under hard (TH: 150 to $300 \mathrm{mg} / \mathrm{l}$ ) to very hard (TH: > $300 \mathrm{mg} / \mathrm{l})$ categories [25].Concentration of total dissolved solids in the groundwater of the study area ranged from 1.39 to $1205.33 \mathrm{mg} / \mathrm{l}$ with an average value of $667.1 \mathrm{mg} / \mathrm{l}$ (table.1). Water can be classified in to fresh (TDS $<1,000 \mathrm{mg} / \mathrm{l}$ ), brackish (. $1,000 \mathrm{mg} / \mathrm{l})$, saline $(>10,000 \mathrm{mg} / \mathrm{l})$ and brine $(1,00,000 \mathrm{mg} / \mathrm{l})$ categories on the basis of TDS concentration.In general, the abundance of major cation and anions were in the order of $\mathrm{Ca}>\mathrm{Mg}>\mathrm{k}>\mathrm{Na}$ and $\mathrm{SO}_{4}>\mathrm{HCO}_{3}>\mathrm{Cl}>\mathrm{CO}_{3}$ respectively. Major water type identified as $\mathrm{Ca}-\mathrm{Mg}-\mathrm{Cl}$ and $\mathrm{Ca}-\mathrm{Mg}-\mathrm{HCO}_{3}$, which is confirmed by the piper trilinear diagram in fig.3 [18]. $\mathrm{Ca}^{2+}$ and $\mathrm{Mg}^{2+}$ are the dominant cation in the groundwater of the study area followed by $\mathrm{Na}^{+}$and $\mathrm{K}^{+}$. The concentration of $\mathrm{Ca}^{2+}$ varies from a minimum value of $34.58 \mathrm{mg} / \mathrm{l}$ to maximum of $333.78 \mathrm{mg} / \mathrm{l}$, with an average value of $80.36 \mathrm{mg} / \mathrm{l}$. Concentration of $\mathrm{Mg}$ varies between 0 to $245.9 \mathrm{mg} / \mathrm{l}$, (average $51.19 \mathrm{mg} / \mathrm{l}$ ). Concentration of $\mathrm{Na}^{+}$and $\mathrm{K}^{+}$varies from 0 to $210 \mathrm{mg} / \mathrm{l}$ and 0.34 to $48.8 \mathrm{mg} / \mathrm{l}$, respectively, in the groundwater of the study area. The anion chemistry shows that $\mathrm{HCO}^{-}$and $\mathrm{Cl}^{-}$are the dominant anions followed by $\mathrm{SO}_{4}{ }^{2-}$ and $\mathrm{NO}_{3}{ }^{-}$in the abundance order of 834.4>405.65>360>65>58.8 (table.1). The measured concentration of $\mathrm{HCO}_{3}{ }^{-}$in the groundwater samples, varies from 64.05 to $405.65 \mathrm{mg} / \mathrm{l}$ with an average value $239.53 \mathrm{mg} / \mathrm{l}$. Weathering of carbonate and /or alumino-silicate rocks with a secondary contribution from dissolution of $\mathrm{CO}_{2}^{-}$gases are the primary source of $\mathrm{HCO}_{3}{ }^{-}$in the groundwater.

The chloride concentration in the groundwater of Bhopalpatnam area, varied between 30 to $360 \mathrm{mg} / \mathrm{l} \mathrm{with}$ an average value of $90.7 \mathrm{mg} / \mathrm{l}$. Chloride presents in a lower concentration in common rock types as compared to other constituents of natural water. It is assumed bulk of the chloride in water is primarily either from atmospheric source or from seawater.

Concentration of nitrate in the analyzed groundwater samples varies between 25 to $65 \mathrm{mg} / \mathrm{l}$ (average $38.77 \mathrm{mg} / \mathrm{l}$ ). Nitrate is an important pollutant in the environment, generally derived from atmospheric precipitation, agricultural fertilizers, human and animal excreta, biological fixation and nitrification of organic $\mathrm{N}$ and $\mathrm{NH}_{4}[5]$.

Concentration of sulphate varies from 0 to $834.4 \mathrm{mg} / \mathrm{l}$; (average $47.51 \mathrm{mg} / \mathrm{l}$ ) concentration of sulphate is relatively higher in the groundwater sample ID 8, (table.1). Sulphate concentration in natural water is usually found between 2 and $80 \mathrm{mg} / \mathrm{l}$ and abnormal higher concentration of sulphate may be attributed to rock weathering or anthropogenic sources like industrial and agricultural effluents [8].

The amount of Fe ranged from 0 to $4.65 \mathrm{mg} / \mathrm{l}$ (average 0.73 ) table.1, exceeding the desirable limit of 0.3 $\mathrm{mg} / \mathrm{l}$ in about 525 of the analyzed groundwater samples. Iron in normal groundwater is mostly in the form of inorganic complexes derived from laterites and other types of soils. Excess Fe in groundwater is mostly accumulated through the industrial effluents discharge.

Fluoride rich minerals are fluorite, apatite, mica, amphiboles and clay. In the study area the major source of $\mathrm{F}$ is gneissic and charnockite rocks, which has high concentration. Important factors that determine concentration of fluoride in groundwater is availability and solubility of $\left(\mathrm{F}^{-}\right)$minerals, $\mathrm{pH}$, temperature, anion exchange capacity of aquifer materials, type of geological materials and residence time, porosity, structures, depth, groundwater age, concentration carbonate and bicarbonates in water [2]. The concentration of fluoride is ranged between, 0.1 and $3.58 \mathrm{mg} / \mathrm{l}$ with an average of $1.71 \mathrm{mg} / \mathrm{l}$. , (table.2). 


\section{CONCLUSIONS}

Evaluation of Physico-chemical parameters reflects that weathering of granitic and silicate rocks are responsible for major ion chemistry of groundwater in Bhopalpatnam area.Water-rock interaction and evapo-transpiration, which were further, influenced by arid to semi-arid climate and low precipitation factors of the area, played crucial role in the concentration of species in groundwater especial the fluoride. Influence of aquifer material and availability of $\mathrm{F}^{-}$rich minerals are instrumental in enrichment of $\mathrm{F}^{-}$in groundwater rather than the inherent chemical characteristics of water. Due to precipitation of calcium, soils become alkaline with high contents of sodium; these conditions allow fluoride to accumulate in water. The structural disturbances and intense weathering processes together with fractured semi-confined aquifer system have accentuated the release of fluoride from rocks and soils to groundwater under the alkaline environment. The groundwater existing in the Bhopalpatnam block, Bijapur-District, Chhattisgarh is significantly affected by the excess concentrations of Fluoride.The results revealed this alarming concentration of the fluoride in the study area of the Bhopalpatnam block Bijapur District. At present, in the study area, the drinking water is being supplied by the Government through the municipal tanks and some other means. Alternatively, the existing groundwater may be effectively utilized in the study area by taking up a pilot projects like de-fluoridation on priority basis. This study will be helpful in solving problem related to drinking water in the study area and further carry out research in this direction.

\section{Acknowledgments}

The authors are thankful to the Principle, Govt.N.P.G. College of Science, Raipur (C.G.) and Head, Department of Applied Geology, National institute of Technology Raipur,(C.G.) for providing necessary permission and facilities to complete the task. Korsa Munna is thankful to U.G.C. for providing Rajiv Gandhi National Fellowship (RGNF) for pursuing doctoral work.

\section{References}

[1] Andeznath, S. K., Suseela, A.K., Ghosh, G., (1999). Fluorosis management in India: The impact due to networking between health and rural drinking water supply agencies, IAHS - AISH Publ 260, pp 159-165.

[2] Apambire, W.B., Boyle, D.R. and Michel, F.A. (1997). Geochemistry, genesis and health implications of fluoriferous groundwater in the upper regions of Ghana. Environ. Geol.,v.33, pp.13-24.

[3] APHA, (1995). Standard methods for the examination of water and waste water, $19^{\text {th }}$ ed., American Public Association, Washington D.C., 1467 p.

[4] APHA, (2012). Standard methods for the examination of water and wastewater. American, Public Health Association, Washington, DC, 1496p.

[5] Appelo caj, Postma, d, (1996). Geochemistry, groundwater and pollution. AA Balkema Publishers, Rotterdam.

[6] Ayoob, S. and Gupta, (2006). Fluoride in drinking water: a review on the status and stress effects. Critical Reviews in Environmental Science and Technology, v.36, pp.433-487.

[7] Back, W. (1966). Hydrochemical facies and ground flow patterns in northern part of Alantic Coastal Plain. USGS Series Professional Paper, 498 - A, p 42.

[8] Berner EK, BernerRA,(1987). The global water cycle: geochemistry and environment. PrenticeHall, Englewood Cliffs.

[9] BIS, (2012). Indian standard specifications for drinking water. IS : 10500, Bureau of Indian Standards, New Delhi. 
[10] Brindha, K,. Rajesh, R., Murugan, R. and Elango, L. (2011). Fluoride contamination in groundwater in parts of Nalgonda district, Andhra Pradesh India. Environ. Monit. Assess., v.172, pp. 481-492.

[11] Fantong WY, Satake H, Ayonghe SN, Suh EC et al, (2009). Geochemical provenance and spatial distribution of fluoride in groundwater of Mayo Tsanaga river basin, Far North Region, Cameroon: implications for incidence of fluorosis and optimal consumption dose. Environ Geochem Health 32:147-163

[12] Gaciri, S.J. and Davies, (1993). The occurrence and geochemistry of fluoride in some natural water of Kenya. Jour. Hydrol., v.143, pp.395-412.

[13] Gibbs RJ,(1970). Mechanism controlling water world chemistry. Science 170:1088-1090.

[14] Jacks, G., Bhattacharya, P., Choudhary., V. and Singh K.P. (2005). Controls on the genesis of some high fluoride groundwater in India. Appl. Geochem.,v. 20, pp.221-228.

[15] Jacks G., Sharma, V. P., \& Sharma, G. K. (1980). Hydrochemical studies, SIDA-assisted groundwater project in Kerala - a report (pp. 1-5).

[16] Mishra, V.P.,P.and Datta, N.K. (1988). Stratigraphy, structure and metamorphic history of Bastar District, Madhya Pradesh.Rec.Geol.Surv.India,v.117,pp.1-26.

[17] Piper AM (1944). A graphical procedure in the geochemical interpretation of water analysis. Trans Am Geoph Union 25: 914 - 928.

[18] Piper,(1953). A graphic procedure in the geochemical interpretation of water analysis. Trans. US Geol Survey. Groundwater Notes, 12.

[19] Radhakrishna, B.P. and Naqvi, S.M. (1986) .Precambrian Continental Crust of India and its Evolution. Jour. Geol., v. 94, pp. 145-166.

[20] Ramamohan Rao, N. V., Rao, N., Surya Prakash Rao, K. and Schuiling, R.D. (1993). Fluorine distribution in waters of Nalgonda district, Andhra Pradesh, India. Environ. Geochem. Health 11, 1247-1253.

[21] Ramesham, V. and Rajagopalan, K.J. (1985). Fluoride ingestion into the natural water of hard rock areas, Peninsular India. Jour. Geol.Soc. India, v. 26, pp.125-132.

[22] Ramesham, V. and Rajagopalan, K. J. (1985). Fluoride ingestion into the natural water of hard rock areas, Peninsular India. Journal of the Geological Society of India, 26, 125-132.

[23] Reddy AGS, Reddy DV, Rao PN, Prasad KM, (2010). Hydrogeochemical characterization of fluoride rich groundwater of Wailpalli Watershed, Nalgonda District, Andhra Pradesh, India. Environ Monit Assess 171: 561- 577.

[24] Santosh, M., Tsunogae, T., IKI, T., Vansutre, S. and HARI, K. R.(2006).Petrology, fluid inclusions and metamorphic history of Bhopalpatnam granulites, Central India. Jour. Asian Earth Sci., v.28, pp.81-98.

[25] Sawyer CN, McCarty PL (1967).Chemistry of sanitary engineers, $2^{\text {nd }}$ edn. McGraw Hill, New York.

[26] Subba Rao, N. (2003). Groundwater quality - focus on fluoride concentration in rural parts of Guntur District, Andhra Pradesh, India. Hydrol. Sci. Jour.,v.48, pp.835-847.

[27] Vansutre, S. and Hari, K.R. (2010). Granulite belts of Central India with special reference to the Bhopalpatnam Granulite Belt : Significance in crustal evolution and implications for Columbia Supercontinent. Jou. Asian Earth Sci., v.39, pp. 794-803.

[28] Yedekar, D.B. Jain, S.C., Nair, K.K.K., Dutta, K.K., (1990). Indian collision suture. Geological Survey of India 29, 1-43. 